\title{
New Method for Early Detection of two Random Amplified Polymorphic DNA (RAPD) Groups of Staphylococcus aureus Causing Bovine Mastitis Infection in Paraná State, Brazil
}

\author{
Dicezar Gonçalves1,2*, Jane Eire Gabriel, Humberto Maciel França Madeira, Guilherme \\ Schnell e Schühli and Vânia Aparecida Vicente \\ ${ }^{I}$ Divisão de Bioprocessos e Biotecnologia; Universidade Federal do Paraná; 81531-990; Curitiba - PR - Brasil. \\ ${ }^{2}$ Pontifícia Universidade Católica do Paraná; Curitiba - PR - Brasil. ${ }^{3}$ Universidade Estadual de Ponta Grossa \\ Ponta Grossa - PR - Brasil
}

\begin{abstract}
The aim of this work was to develop a fast and accurate molecular approach to allow early detection of two RAPD groups of S. aureus causing bovine mastitis. Seventy five S. aureus isolates from infected animals were characterized by RAPD. Genomic fragments isolated from the unique bands present in either group were cloned and sequenced. Based on the DNA sequences, specific primers were designed to allow for the simultaneous detection of either group by multiplex PCR of S. aureus DNA isolated from clinical and subclinical bovine mastitis. Results showed that these proposed primers set could be used to detect various clinical and subclinical S. aureus isolates as well as the detection of the microorganism in bulk milk. Their use as a specific method for effective and early diagnostic tool for $\mathrm{S}$. aureus infection in dairy herds is suggested.
\end{abstract}

Key words: Staphylococcus aureus, molecular markers; subclinical mastitis, clinical mastitis, mastitis detection

\section{INTRODUCTION}

The economic importance of the $S$. aureus causing clinical and subclinical bovine mastitis is largely recognized (Myllys et al, 1997). Clinical mastitis is the single most costly disease of dairy cattle resulting in the reduction of milk yield and quality (Riekerink et al, 2007a). The control of precalving subclinical mastitis by somatic cell count (SCC) is an indicator of intramammary infection (IMI) in bovines (Riekerink et al, 2007b). Udder edema and number of neutrophils in milk (Detilleux, 2004) are also important factors (Compton et al, 2007a). Precalving subclinical mastitis was diagnosed in
$18.5 \%$ of quarters of the udder (Compton et al, 2007b) and increase in standard deviation log of SCC was associated with the presence of $S$. aureus clinical mastitis in bovines (Green et al,(2004). Mastitis persists for long-term and may be detected by Pulsed Field Gel Eletrophoresis (Rabello et al, 2005; Anderson and Lyman, 2006). $S$. aureus was isolated coincidently from the herd with problems of increased number of milk SCC, neutrophils and decreased milk production in infected animals. Studies by Cullor (1992) and Gonçalves and Kozicki, (1997) indicated that the disease was present in $15 \%$ of all the dairy herds in the world, with a prevalence rate of $50 \%$ in

*Author for correspondence: dicezar.zmv@uol.com.br 
U.S.A. and classified as either contagious or environmental based upon their primary reservoir and transmission mode (Parker et al, 2007).

$S$. aureus is a contagious pathogen commonly transmitted among the cows by contact with infected milk and the infection reach up to $32 \%$ of the herd (Pitkälä et al, 2004). This pathogen is particularly important because it causes mainly subclinical forms of infectious mastitis that are often difficult to detect by the herdsman (Compton et al, 2007b). The evolution of the infection turns difficult its treatment and increases the disease level (Reksen et al, 2006). Upon infection of the secretory tissue, the pathogen diffuses and encysts (Smith, 1977 and Hensen et al, 2000). This condition reinforces the necessity of early diagnosis to prevent the spread of the disease and management of the contaminated milk with $S$. aureus.

In Paraná State, Brazil, the estimated annual economic loss due to mastitis range from $\$ 95.62$ to 142.42 per cow (Swinkels et al, 2005). These costs include reduced yield, discarded milk, drug therapy, veterinarian costs, premature culling, and increased labor. Fat and protein production is reduced by $9.0 \%$ in the clinical mastitis cases (Hagnestam et al, 2007).

Several biochemical and molecular methods are used in the investigation of $S$. aureus in bovine infections (Hartstein et al, 1989; Williams et al, 1990; Prevost et al, 1991; Kosteman et al, 1992 and Kapur et al, 1995). Current identification methods are based on microbiological culture of milk and biochemical tests on the isolated bacteria. At present, species identification by standard methods is laborious and takes at least 2 to 3 days to yield results. Other tests are commonly employed in Brazil to detect the occurrence of the subclinical mastitis, as California Mastitis Test, (Schalm and Noorlander, 1957; Riekerink et al, 2007b). However, since specific identification of the causal agent in Brazil is limited to tradicional methods, PCR-based approaches have been developed to identify the mastitis pathogens, which provides a promising alternative for the rapid identification of bacteria. In addition, the sensitivity of PCR-based assays tends to be better than bacterial cultures (Forsman et al, 1997; Kim et al, 2001) allowing the detection of small number of microorganisms.

These methods may be extremely important when rapid and accurate identification of pathogenic bacteria is required. Different PCR-based methods have been developed for specific and sensitive detection of mastitis pathogens directly in milk. Forsman et al, (1997) identified by PCR test the Staphylococcus spp. isolates in Russia, Germany and Denmark, but no cross reactivity could be observed investigating staphylococcal reference strains. Riffon et al, (2001) developed molecular probes reacting in PCR with bacterial DNA from bovine milk providing direct and rapid detection of Escherichia coli, S. aureus, Streptococcus agalactiae, S. dysgalactiae, S. parauberis and $S$. uberis, using universal primers in Canada. In this bacterial group, Meiri-Bendek et al, (2002) using $16 \mathrm{~S}$ subunit of the rRNA genes, developed a specific PCR reaction to detect Streptococcus agalactiae in the milk of subclinical mastitis. Cremonesi et al, (2006) developed a method to extract DNA directly from the main Gram-positive bacteria known to cause bovine mastitis. Some alternative methods for diagnosis were also developed for detection in cows. Puetkes et al, (2001) and Eckersall et al, (2006) developed a multiplex PCR approach to detect the disease directly from milk cows or alternatively from dairy products, using mRNA 23S and genomic DNA. Youngerman et al, (2004) using CXCR2, a chemokine receptor required for neutrophil migration to infections sites and which contains single nucleotide polymorphisms (SNP) within the gene, showed association of CXCR2 genotypes, with subclinical and clinical mastitis. Ramesh et al, (2002) and Graber et al, (2007) obtained high correlation $(R=0.925)$, with the PCR methods to diagnose $S$. aureus mastitis. Gillespie and Oliver, (2005), using RT-PCR identified $91.7 \%$ of $S$. aureus in milk and Moon et al, (2007), based on coagulase gene polymorphism, observed relations with enterotoxins-producing by $S$. aureus strains. The objective of this work was to detect S. aureus by means of multiplex PCR using a set of specific primers, by previous extraction of DNA, cloning and sequencing of monomorphic bands from isolated $S$. aureus DNA in order to make a rapid and specific identification of the microorganism.

\section{MATERIALS AND METHODS}

A total of $75 \mathrm{~S}$. aureus isolates were isolated from the bovine udder proceeding from 240 different cases of clinical and subclinical infections. Morphological and biochemical identifications were carried out following Koneman et al, (2001). 
Samples were stored in $7.5 \% \mathrm{NaCl}$ agar manitol at $4^{\circ} \mathrm{C}$. They are cultivated in $\mathrm{BHI}$ broth at $37^{\circ} \mathrm{C}$ for $43 \mathrm{~h}$. Genomic DNA was isolated by means of CTAB (cetiltrimetilamonium bromide), (Dellaporta et al, 1983; Doyle and Doyle 1987; Daneshwar and Sher-Ullah, 2004).

\section{Genetical variability and polymorphism analysis of 75 isolates of $S$. aureus}

To carry out the Random Amplified Polymorphic DNA (RAPD) technique the following primers were used: OPJ 5 (5'CTC CAT GGG G 3'); OPJ 6 (5' TCG TTC CGC A 3'); Primer 786 (5' GCG ATC CCC A 3'); Primer 797 (5' AGC GTC ACT G 3') and Primer 798 (5' TGA CCC GCC 3'), based in Myllys et al, (1997) and Pereira et al, (2002) and OPA 2 (5' TGC CGA GCT G 3') (Spolidorio et al, 2003). The DNA amplifications reactions were made according Pereira et al, (2002). A final volume of $14 . .9 \mu \mathrm{L}$ contained $20 \mathrm{ng}$ of purified DNA and $1.0 \mathrm{U}$ of Taq DNA polymerase, $3 \mathrm{mM} 1^{-1} \mathrm{MgCl} 2,50 \mathrm{mM} 1^{-1} \mathrm{KCl}, 10$ $\mathrm{mM} 1^{-1}$ Tris- $\mathrm{HCl}(\mathrm{pH} 8.8), 200 \mu \mathrm{M}$ of Mix dNTP, and $0.5 \mathrm{mM}$ of each primer. The mixture was subjected to a initial denaturation at $94{ }^{\circ} \mathrm{C}$ for 5 min, followed by 45 cycles of $30 \mathrm{~s}$ at $94^{\circ} \mathrm{C}, 30 \mathrm{~s}$ at $36^{\circ} \mathrm{C}$ and $1 \mathrm{~min} 30 \mathrm{~s}$ at $72^{\circ} \mathrm{C}$. A subsequent final cycle of extension at $72^{\circ} \mathrm{C}$ for $1 \mathrm{~min}$ was carried out in a thermocycler (PT100 Perkin Elmer). The amplification products were analyzed in $1.6 \%$ agarose gel (TBE buffer at $114 \mathrm{mV}$ ). Two strains of S. aureus, ATCC 25923 and ATCC 6538 and one out-group were also included (Streptococcus spp.) as references strains. The polymorphism analysis of the isolated strains from the clinical and subclinical cases was carried out under phenetical methods applying UPGMA (Unweighted Pair Group Method with Arithmetic Mean) using the similarity coefficient of Jaccard in the NTSYS program, version 2.1 (Numerical Taxonomy and Multivariate Analysis System), (Rohlf, 2000). The support values of the groups were computed by bootstrap (Felsenstein 1986, 1993; Hillis and Bull, 1993).

\section{Isolation of the RAPD genomic DNA fragments}

Two polymorphic and monomorphic bands were selected, corresponding to both mastitis cases types and the isolation of DNA fragments was due to the similarity in each group. The DNA fragments were cut and purified by the Purelink Quick Gel Extraction Kit (Invitrogen Life).

\section{Fragment cloning in $E$. coli}

Fragments were prepared according to the pGEM ${ }^{\circledR}$ Systems, (Promega Corporation) and cloning in the E. coli TOP10 F1 (Soares et al, 2001). For visualization of the possible insertion fragments in the plasmids, eletrophoresis in agarose gel $(0.8 \%)$ was carried out after the treatment with EcoRI restriction enzyme (Invitrogen Life).

\section{AmpliSeq reactions}

All the reactions were prepared with the Kit DYEnamic $^{\mathrm{TM}}$ ET dye terminator MegaBACE ${ }^{\mathrm{TM}}$ (Amersham). Universal primers used in the reactions for plasmid amplification were synthesized and purified by means of Invitrogen ${ }^{\mathrm{TM}}$ Life, according Murphy et al, (2005): pUC/M 13 Forward Sequencing Primer: 5' CGT TGT AAA ACG ACG GCA AGT 3' and pUC/M13 Reverse Sequencing Primer: 5' TTT CAC ACA GGA AAC AGC TAT GAC 3'. Reaction systems consisted of $3.0 \mu \mathrm{L}$ mix ET dye terminator; two primers in equal concentration 5-500 mol $1^{-1}$; dNTPs in a final concentration of $125 \mathrm{~mol} \mathrm{l}^{-1}, 50$ $500 \mathrm{mg} \mathrm{l}^{-1}$ of DNA in a final vol. of $7.5 \mu \mathrm{L}$. All the reactions were cycled at $95^{\circ} \mathrm{C}$ for $2 \mathrm{~min}$, followed by 35 cycles at $95^{\circ} \mathrm{C}$ for $20 \mathrm{~s}$ and $60^{\circ} \mathrm{C}$ for $2 \mathrm{~min}$. The PCR product was purified by ammonium acetate $7.5 \mathrm{~mol} 1^{-1}$ and precipitated by ethanol in successive centrifugations (Murphy et al, 2005). Samples were sequenced by electrophoresis in an ABI 377 (Applied Biosystems). The primers were designed considering the sequences obtained.

\section{Sequences edition and primer design}

Edited sequences (GenBank: Access AM749799 to $S$. aureus RAPD clinic fragment and AM749800 to $S$. aureus RAPD subclinic fragment), examined trough PerlPrimer (Marshall, 2004) allowed the design of the specific primers set for clinical and subclinical strains. For the subclinical strain, the forward primer FSBSTAPH: 5' CCA AAC TTG GTA ATT GAA GGA C 3', displayed an optimum annealing temperature of 59.78 ${ }^{\circ} \mathrm{C}$ and the reverse primer RSBSTAPH: $5^{\prime}$ ACA ATG TTG AAA CTC AGA CGT C 3', displayed an optimum annealing temperature of $61.41^{\circ} \mathrm{C}$. For the clinical strain the designed primers were the forward FCSTAPH: 5' TTG ATC TGG ATA CGA TGG AAA GG 3' with an optimum annealing temperature of $62.48^{\circ} \mathrm{C}$ and a reverse primer RCSTAPH: 5' TTA AGT ATA 
AGC TTC ACG CCG AG 3' with an optimum annealing temperature of $62.72{ }^{\circ} \mathrm{C}$.

\section{Markers evaluation and protocol development}

A multiplex PCR according to Vandercan et al,(1995), Pinekter et al, (2001) and Vannuffel et al, (2003) was prepared applying the proper annealing temperature suggested by the software (PerlPrimer) with a final volume of $25.0 \mu \mathrm{L}$. The reaction comprised $2.5 \mu \mathrm{L}$ of PCR buffer minus $\mathrm{Mg}$ (final concentration 1X), 1.0 $\mu \mathrm{L}$ of mix dNTP's (final concentration of $0.2 \mathrm{mM}$ ), Primer mix in final concentration of $0.5 \mu \mathrm{M}, 2.5 \mathrm{U}$ of Taq, $25.0 \mathrm{ng}$ of genomic DNA $(0.5 \mu \mathrm{l})$ and $17.5 \mu \mathrm{L}$ of Milli Q filtered water. The amplifications were preceded with 35 cycles with denaturation of $45 \mathrm{~s}$ at $94^{\circ} \mathrm{C}$, annealing of $45 \mathrm{~s}$ at $60^{\circ} \mathrm{C}$ and extension of 2 min at $72^{\circ} \mathrm{C}$. The multiplex PCR products were examined with agarose gel $1 \%$.

\section{RESULTS AND DISCUSSION}

\section{Strain recognition and DNA isolation}

In the present work, $31.25 \%$ of the mastitis cases sampled were confirmed as $S$. aureus infection by morphological and biochemical analysis (Gonçalves et al 2001). Several procedures for the early identification and fast recognition of $S$. aureus infections are essential for health studies (both animal and human) due to economical importance in dairy industry. Amplification analysis allowed the identification of two main groups (Fig.1) based on the presence of distinct monomorphic bands. These bands were fully congruent with the identification of the clinic and subclinical strains of $S$. aureus.

A multiplex PCR according to Vandercan et al, (1995), Pinekter et al, (2001) and Vannuffel et al, (2003) was prepared applying the proper annealing temperature suggested by the software (PearlPrimer) with a final volume of $25.0 \mu \mathrm{L}$. The reaction comprised $2.5 \mu \mathrm{L}$ of PCR buffer minus $\mathrm{Mg}$ (final concentration 1X). 1,0 $\mu \mathrm{L}$ of mix dNTP's (final concentration of $0.2 \mathrm{mM}$ ), Primer mix in final concentration of $0.5 \mu \mathrm{M}, 2.5 \mathrm{U}$ of Taq, $25.0 \mathrm{ng}$ of genomic DNA $(0.5 \mathrm{~mL})$ and $17.5 \mu \mathrm{L}$ of Milli $Q$ filtered water. The amplifications were proceeded with 35 cycles with denaturation of $45 \mathrm{~s}$. The subclinical sample displayed a $950 \mathrm{bp}$ band while the subclinical sample was smaller $800 \mathrm{pb}$ band (Fig. 2).

In addition to its fast performance, the RAPD method assures a high confidence in its diagnosis, being very sensitive to $S$. aureus studied strains. RAPD data allowed a clear distinction between two clades in the identification of the strains (Fig.1). The identification was fully congruent with the clinical picture noted in the studied infections. Each group of strains might correspond to one cluster of mutually similar genotypes.

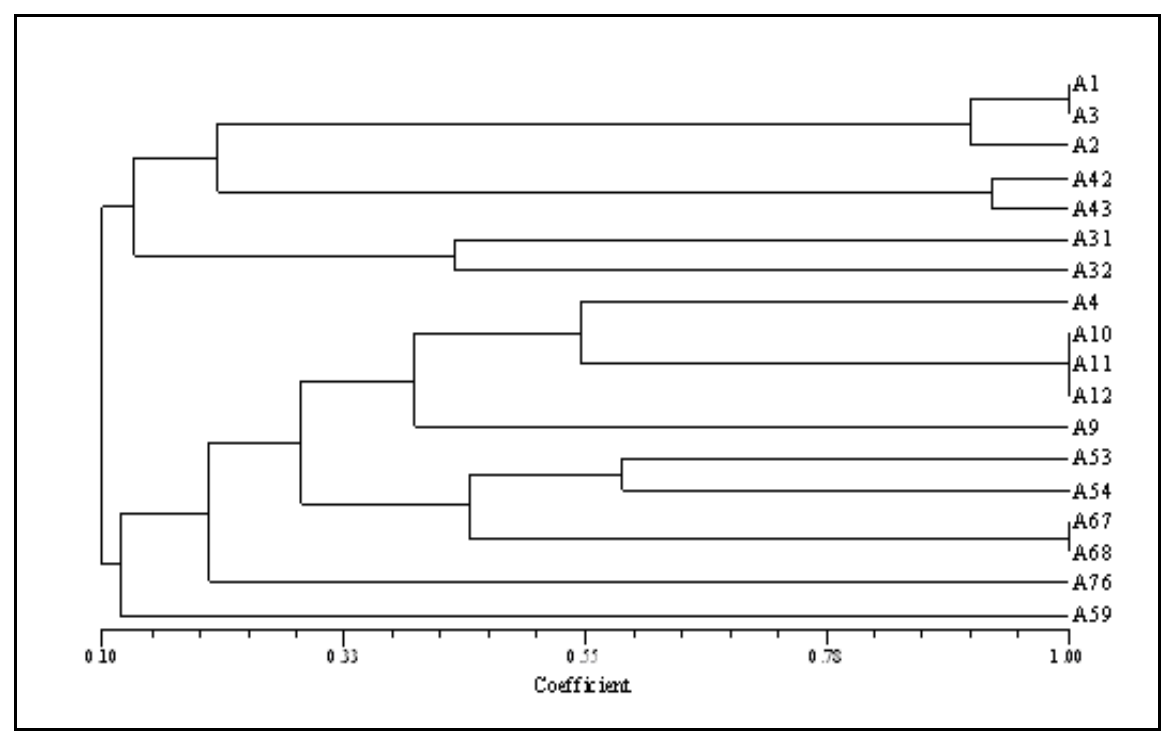

Figure1 - Some of the strains studied show the formation of two S. aureus groups (I - Clinical and II - Subclinical) with low similarity between the groups but with very high levels of security $(\mathrm{p}<0.001)$. 


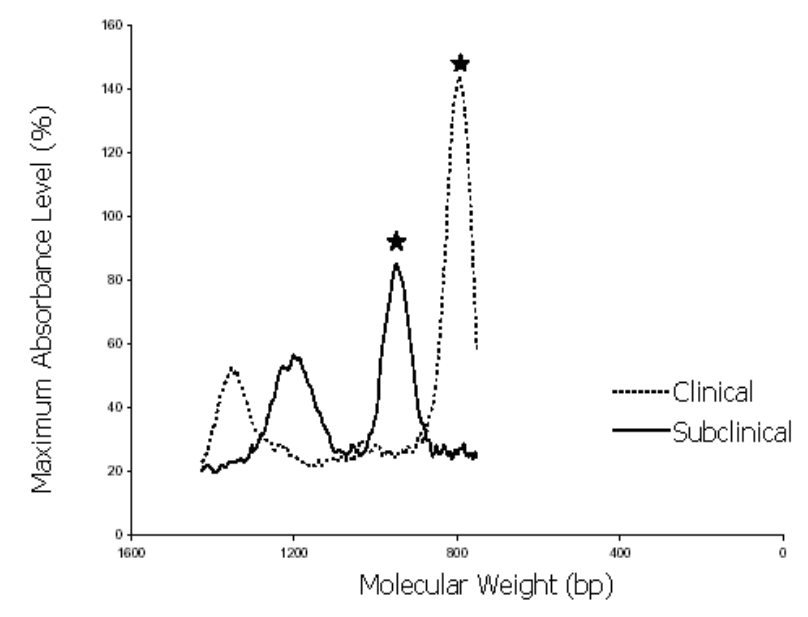

Figure 2 - Size and intensity (in maximum absorbance) by samples proceeding from clinical and subclinical mastitis. Bands were eluted with Purelink kit. A star indicates the position of band peak of interest (around of 950 for the subclinical sample and 800 for the clinical).

\section{AmpliSeq reactions}

Both inserts were effectively amplified with the proper PCR reaction suggested by the plasmid manufacturer protocol (pGEM® Vector Systems). The results are presented in Fig 3. The two distinctive monomorphic bands were recovered displaying the same size of the original excised bands (950 bp for the subclinical sample and 800 bp for the clinical) (Fig.3).

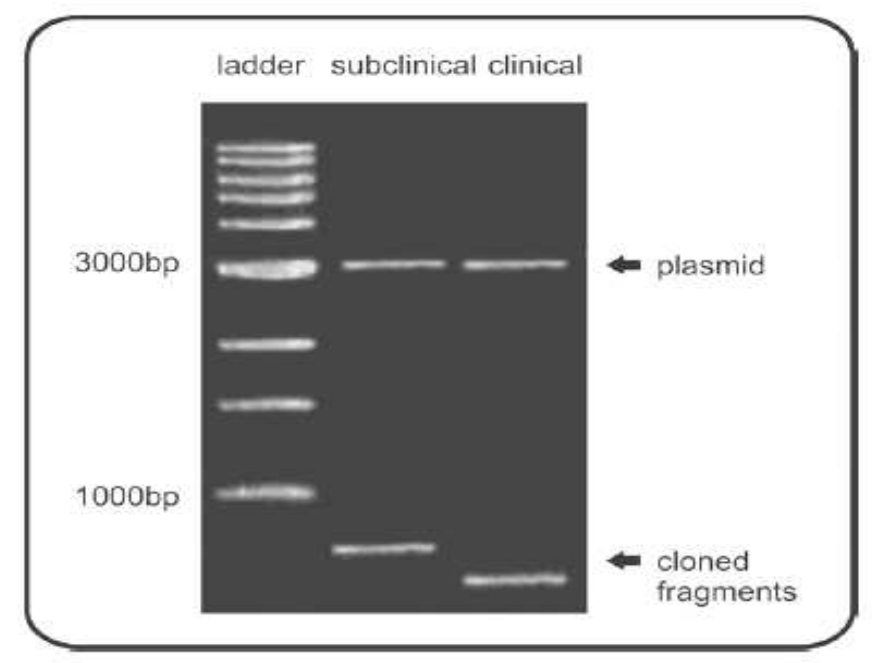

Figure 3 - Positively cloned strains in agarose gel $(1 \%)$. Ld = ladder (1 kbases). The 3 kbases bands correspond to the plasmid pGEM ${ }^{\circledR}$-T Easy Vector previously digested by EcoRI.

\section{Multiplex PCR}

Amplification of the desired regions starting from genomic DNA was always successful using the four designed primers. It was equally effective for single PCR or multiplex PCR reactions carried out under similar conditions. Figure 4 shows agarose gel $(1 \%)$ for the specific identification of clinical and subclinical isolated strains after multiplex PCR. 


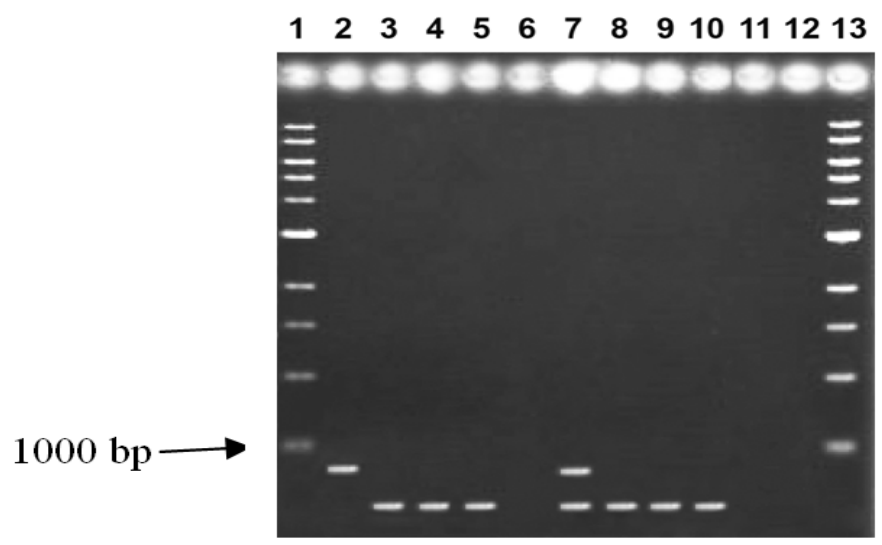

Figure 4 - Multiplex PCR results in 1\% agarose gel showing amplifications of genomic DNA. Lanes: 1=Ladder $1 \mathrm{~kb} ; 2=$ subclinic strain; $3=$ clinic strain; 4 and 5= samples containing clinic strains, proceeding of illness cases; $6=$ empty lane; $7=$ subclinic and clinic strains observed in milk tank with capacity of $5.000 \mathrm{~L}$ of milk; $8=$ clinic strain observed in milk tank with capacity of 500L of milk; 9=ATCC 25923; 10=ATCC 6538; 11=Streptococcus mutans; 12=Escherichia coli; 13=Ladder $1 \mathrm{~kb}$.

In this study, 75 field $S$. aureus were identified using the set of four primers resulting in amplifying the desired fragment and the reference strains ATCC 25923 and ATCC 6538 samples. Also, $S$. aureus in milk samples collected directly from the milk bulk tank according to Kim et al, (2001), (for total DNA extraction) were positively detected. To assure the specificity of the primers, the amplification of $S$. mutans and E. coli was attempted but the primers failed in their amplification. The development of a fast diagnosis tool of the subclinical strain was priority. The multiplex PCR approach allowed the detection of both types of strains. The method was able to detect successfully $S$. aureus contamination even in high-diluted milk samples as the ones taken from a 5000L bulk milk tank. These results suggested another useful application to detect eventual contaminations in the stored milk.

This protocol could be used as a quality inspection tool for producers and in the chain of distribution, contributing to healthy herds and high ranks of quality for the milk producers.

\section{ACKNOWLEDGMENTS}

The authors are grateful to Dr. Emanuel M. de Souza, Mr. Helisson Faoro and Mr. Valter Baura (Biochemistry Department to UFPR) for their technical assistance. Thanks are due to PUCPR and UFPR, for the financial support.

\section{RESUMO}

Esta pesquisa objetivou o desenvolvimento de técnica rápida e eficiente para diagnosticar precocemente diferentes linhagens de $S$. aureus causadoras de mastite bovina. Como resultados da metodologia empregada, foram isoladas duas linhagens destas bactérias que causam diferentes tipos de mastite bovina. Os fragmentos de DNA genômico caracterizando ambas as linhagens, por meio de RAPD foram inseridos em vetor plasmidial $p G E M$ e clonados por meio de clones T10 F1 de Escherichia coli. As sequiências obtidas permitiram desenhar iniciadores específicos para o reconhecimento de ambas as linhagens, os quais foram testados com amostras de $S$. aureus e com outras linhagens próximas. $\mathrm{O}$ diagnóstico por meios moleculares, pode ser realizado diretamente de amostras coletadas de rebanhos leiteiros assim como dos equipamentos de ordenha. A significância deste estudo consiste em um rápido e acurado método para localizar animais infectados, representando importante ferramenta no manejo do rebanho, na redução de custos com tratamentos e, rápida recuperação de rebanhos infectados. 


\section{REFERENCES}

Anderson, K. L. and Lyman, R.L. (2006), Long -Term Persistence of Specific Genetic Types of MastitisCausing Staphylococcus aureus on Three Dairies. J. Dairy Sci., 89, 4551-4556.

Compton, C.W.R.; Heuer, C.; Parker, K.; McDougall, S. (2007a), Risk Factors for Peripartum Mastitis in Pasture-Grazed Dairy Heifers. J. Dairy Sci., 90, 4171-4180.

Compton, C. W.R.; Heuer, C.; Parker, K.; McDougall, S. (2007b), Epidemiology of Mastitis in PastureGrazed Peripartum Dairy Heifers and Its Effects on Productivity. J. Dairy. Sci., 90, 4661-4669.

Cremonesi, P.; Castiglioni, G.; Malferrari, I.B. (2006), Improved method for rapid DNA extraction of mastitis pathogens directly from milk. J. Dairy Sci., 89, 163-169.

Cullor, J.S. (1992), Mastitis in dairy cows. Does it hinder reproductive performance? Vet. Med., 8, 830835.

Daneshwar, P. and Sher-Ullah, S.J. (2004), Genomic Extraction From Victoria amazonica. Plant. Mol. Biol. Rep. , 22, 195-196.

Dellaporta, S. L.; Wood, J.; Hicks, J.B. (1983), A plant DNA minipreparation: versión II. Plant Mol Biol Rep., 1, 19-21.

Detilleux, J. C. (2004), Neutrophils in the War against Staphylococcus aureus: Predator-Prey Models to the Rescue. J. Dairy Sci., 87, 3716-3724.

Doyle, J.J. and Doyle, J.L. (1987), A rapid DNA isolation procedure for small quantities of fresh leaf tissue. Phytochem. Bull., 19, 11-15.

Eckersall, P.D.; Young, F. J.; Nolan, A. M.; Knight, C. H.; Mc Comb, C.; Waterston, M. M.; Hogarth, C. J.; Scott, E. M.; Fitzpatrick, J. L. (2006), Acute Phase Proteins in Bovine Milk in Experimental Model of Staphylococcus aureus Subclinical Mastitis. J. Dairy Sci., 89, 1488-1501.

Felsenstein, J. (1986-1993), PHYLIP (Phylogeny Inference Package) version 3.5c. (DNAPARS)-DNA Parsimony Program. Seattle Distributed by the author. Department of Genetics, University of Washington.

Forsmann, P.; Tilsala-Timisjarvi, A.; Alatossava, T. (1997), Identification of staphylococcal and streptococcal causes of bovine mastitis using 16S-23S rRNA. Microbiol., 143, 3491-3500.

Gillespie, B. E. and Oliver, S. P. (2005), Simultaneous Detection of Mastitis Pathogens, Staphylococcus aureus, Streptococcus uberis and Streptococcus agalactiae Multiplex Real-Time Polimerase Chain Reaction. J. Dairy Sci., 88, 3510-3518.

Gonçalves, D. and Kozicki, L .E. (1997), Biochemical and immunological profiles during the parturition period in dairy cows, with and without placental retention and mastitis. Braz. J. Vet. Res. Anim. Sci., 34 (6), 371-382.
Graber, H. U.; Casey, M. G.; Naskova, J.; Steiner, A.; Schaeen, W. (2007), Development of a Highly Sensitive and Specific Assay to Detect Staphylococcus aureus in Bovine Mastitic Milk. J. Dairy Sci., 90, 4661-4669.

Green, M. J.; Green, L. E.; Schukken, Y. H.; Bradley, A. J.; Peeler, E. J.; Barkema, H. W.; Haas de, Y.; Collis, V. J.; Medley, G. F. (2004), Somatic Cell Count Distributions During Lactation Predict Clinical Mastitis. J. Dairy Sci., 87, 1256-1264.

Hagnestam, C., Emanuelson, U., Berlung, B. (2007), Yield Losses Associated with Clinical Mastitis Occuring in Different Weeks of Lactation. J. Dairy Sci., 90, 2260-2270.

Hartstein, A.I.; Morthland, V.H.; Eng, S. (1989), Restriction enzymes analysis of plasmid DNA and bacteriophage typing of paired $S$. aureus blood culture isolates. J. Clin. Microbiol , 27, 1874-1879.

Hensen, S.M.; Pavičic, M.J.A.M.P.; Lohuis, J.A.C.M.; Poutrel, B. (2000), Use of Bovine Primary Mammary Epithelial Cells for the Comparison of Adherence and Invasion Ability of Staphylococcus aureus Strains. J. Dairy Sci., 83 (3), 418-429.

Hillis,D.M and Bull, J.J (1993), An empirical test of bootstrapping as a method for assessing confidence in phylogenetic analysis. Syst. Biol., 42, 17-48.

Kapur,V.; Sischo, W.M.; Green, R.S. (1995), Molecular population genetic analyses of Staph. aureus recovered from cows. J. Clin. Microbiol., 33, 376380.

Kim,C.H.; Khan, M.; Morin, D.E.; Hurley, W.L.; Tripathy, M.; Kehrli Jr, M.; Oluocht, A.O.; Kakoma, I. (2001), Optimization of the PCR for detection of Staph. aureus nuc. Gene in the milk. J. Dairy Sci., 84, 74-83.

Koneman, E.W.; Allen, S.D.; Janda, W.M.; Schreckenberger, P.C.; Wn, W.C. (2001), In Diagnóstico Microbiológico- Texto e Atlas Colorido. 5. ed. MEDSI, 11-16.

Kosteman, J.R.; Edling, T.D.; Lipuma, J.J.; Stull, T.L. (1992), Molecular Epidemiology of pseudomonas cepacia determined by polymerase chain reaction ribotiping. J. Clin. Microbiol., 30, 2004-2087.

Marshall, O.J. (2004), PerlPrimer: cross-platform, graphical primer design for standard, bisulphite and real-time PCR. Bioinformatics, 20, 2471-2472

Meiri-Bendek, I.; Lipkin, E.; Friedman, A.; Leitner, G.; Saran, A.; Friedman, S.; Kashi, Y. (2002), A PCRbased method for the detection of Streptococcus agalactiae in milk. J. Dairy Sci., 85, 1717-1723.

Moon, J. S.; Lee, A.R.; Kang, H. M.; Lee, E. S.; Joo, Y. S.; Park, Y. H.; Kim, M.N.; Koo, H. C. (2007), Antibiogram and Coagulase Diversity in Staphylococcal Enterotoxin-Producing Staphylococcus aureus from Bovine Mastitis. J. Dairy Sci., 90, 1716-1724. 
Murphy, K.M.; Berg, K.D.; Ehleman, J.R. (2005), Sequencing of Genomic DNA by Combined amplification and Cycle Sequencing reaction. Clin. Chem., 51 (1), 35-39.

Myllys, V.; Ridell, J.; Bjorkroth, J.; Biese, I.; Pyorala, S. (1997), Persistence in bovine mastitis of Staph. aureus clones as assessed by random amplified polymorphic DNA analysis, ribotyping and biotyping. Vet. Microbiol., 51, 245-251.

Parker, K.I.; Compton, C.; Anniss, F.M.; Weir, A.; Heuer, C., Mc Dougall, S. (2007), Subclinical and Clinical Mastitis in Heifers Following the Use of a Teat Sealant Precalving. J. Dairy Sci., 90, 207-218.

Pereira, M.S.V.; Leal, N.C.; Leal, T.C.A.; Sobreira, M.; Almeida, A.M.P.; Siqueira-Júnior, J.P.; CamposTadaki, G.M.(2002), Typing of human and bovine Staph. aureus by RAPD and ribotypyng-PCR. Lett. App. Microbiol., 35, 32-36.

Pinekter, P.; Mansell, P.D.; Browning, G.F. (2001), Multiplex Polymerase Chain Reaction Assay for Simultaneous Detection of Staph. aureus and Streptococcal Causes of Bovine Mastitis. J. Dairy Sci., 84, 1140-1148.

Pitkälä, A.; Haveri, M.; Pyörälä, S.; Myllys, V.; Honkanen-Buzalski, T. (2004) Bovine Mastitis in Finland 2001 - Prevalence, Distribution of Bacteria, and Antimicrobial Resistence. J. Dairy Sci., 87, 24332441.

Prevost, G.; Pottecher, B.; Dalhet, M. (1991) Pulsedfield gel Electrophoresis as a new epidemiological tool for monitoring methicilin- Resistant Staph. aureus in a intensive care unit. J. Hosp. Infect. (17), 255-259.

Puektes, P.; Mansell, P. D.; Browning, G. F. (2001), Multiplex Polymerase Chain Reaction Assay for simultaneous Detection of Staphylococcus aureus and Streptococcal Causes of Bovine Mastitis. J. Dairy Sci., 84 (5), 1140-1148.

Rabello, R. F., Souza, C.R.V.M., Duarte, R. S., Lopes, R. M.M.; Teixeira, L. M.; Castro, A. C. D. (2005), Characterization of Staphylococcus aureus Isolates Recovered from Bovine Mastitis in Rio de Janeiro, Brazil. J. Dairy Sci., 88, 3211-3219.

Ramesh, A.; Padmapriya, B. P.; Chandrashekar, A.; Varadaraj, M. C. (2002), Application of a convenient DNA extraction method and multiplex PCR for the direct detection of Staphylococcus aureus and yersinia enterocolitica in milk samples. Mol. Cell. Prob., 16, 307-314.

Reksen, O.; Sølverød, L.; Branscum, A.J.; Østerås (2006), Relationship Between Milk Culture Results and Treatment for Clinical Mastitis or Culling in Norwegian Dairy Cattle. J. Dairy Sci., 89, 29282937.

Riekerink, R.G.M.; Barkema, H.W.; Stryhn, H. (2007a), The Effect of Season on Somatic Cell Count and the Incidence of Clinical Mastitis. J. Dairy Sci., 90, 2260-2270.

Riekerink, R. G. M.; Barkema, H. W.; Veenstra, W.; Berg, F. E.; Stryhn, H.; Zadoks, R. N. (2007b), Somatic Cell Count During and Between Milkings. J. Dairy Sci, 90, 3733-3741.

Riffon, R.; Sayasaith, K.; Khalil, H.; Dubreuil, P.; Drolet, M.; Lagacé, J. (2001) Development of a rapid and sensitive test for identification of major pathogens in bovine mastitis by PCR. J. Clin. Microbiol., 39 (7), 2584-2589.

Rohlf, F.J. (2000), NTSYS-PC, Numerical taxonomy and multivariate analysis system - Version 2.1. New York, Applied Biostatistic Inc., 44 p.

Schalm, O. W. and Noorlander, D. O. (1957), Experiments and observations leading to development of the California mastitis test. J. Am. Vet. Med. Assoc., 130- 199.

Smith, H. (1977), Microbial Surfaces in Relation to Pathogenicity. Bacteriol. Rev., 41 (2), 475-500.

Soares, M. J. S.; Teixeira, L. A.; Nunes, M. R.; Carvalho, M. C. S.; Ferreira-Carvalho, B. T.; Figueiredo, A. M. S. (2001) Analysis of different molecular methods for typing methicilin-resistent Staphylococcus aureus isolates belonging to the Brazilian epidemic clone. J. Med. Microbiol., 50, 732-742.

Spolidorio, D.M.P.; Hofling, J.F.; Pizzolito, A. C.; Rosa, E. A.; Negrini, T. C.; Spolidorio, L. C. (2003), Genetic polymorphism of Streptococcus mutans in brazilian family members. Braz. J. Microbiol. 34, 3, 213-217.

Swinkels, J.M.; Hogeveen, H.; Zadoks, R.N. (2005), A partial Budget Model to Estimate Economic Benefits of Lactational Treatment of Subclinical Staphylococcus aureus Mastitis. J. Dairy Sci., 88, 4273-4287.

Vannuffel, P.; Gigi, J.; Ezzedne, H.; Sumer, A.; Daneshwar, P.; Sher-Ullah, S.J. (2003), Isolation of DNA for RAPD Analysis from Dry Leaf Material of Some Hisperis L. Specimens. Plant. Mol. Biol. Rep., 21, 461-462.

Vandercam, B.; Delmel, M.; Wanters, G.; Gala, J.L. (1995), Especific Detection of Methicilin-Resistant Staph. Species by Multplex PCR. J. Clin. Microbiol., 33 (11), 2864-2867.

Williams, J.G.K.; Kubelik, A.R.; Livak, K.J. (1990), DNA polymorphisms amplified by binary primers are useful as genetic markers. Nucl. Ac. Res., 18, 65316535 .

Youngerman, S. M.; Saxton, A. M.; Oliver, S. P.; Pighetti, G. M. (2004), Association of CXCR2 Polymorphism with Sub clinical and Clinical Mastitis in Dairy Cattle. J. Dairy Sci., 87, 2442-2448.

Received: May 13, 2008; Revised: October 21, 2009; Accepted: October 21, 2009. 